\title{
THE FATIGUE DESIGN OF GAS STORAGE SYSTEMS USING FRACTURE MECHANICS
}

P. Hopkins and D. G. Jones

British Gas Corporation, Engineering Research Station, Newcastle upon Tyne, NE99 1LH, England

\section{ABSTRACT}

This paper describes the analytical and experimental studies conducted to produce a suitable fatigue design curve for large scale underground high pressure gas storage vessels. These vessels can be operated at stres difficult to inspect during service.

Full scale fatigue tests on vessels containing artificial defects and fatigue fracture mechanics analyses allowed the fatigue lives of the fatigue fracture mechanics analyses allowed the fatigue lives of the fatigue crack growth fractography of the failed test vessels were used to igue crack growth fractography of the failed test vessels were used to demonstrate the ability or a periodic high level pressure test to define a safe fatigue life.

\section{KEYWORDS}

Fatigue design; gas storage vessels; fracture mechanics; pressure test; periodic inspections.

\section{INTRODUCTION}

Industrial and domestic demand for gas has never been constant and ther has always been a need for storage systems to store gas during the night and release it during peak periods in the daytime (Sykes, Brown, 1975).

Gas storage can be achieved using a variety of plant and methods. An attractive form of storage is known as a below-ground pipe array. These pipe arrays are generally $1066 \mathrm{~mm}$ diameter linepipe laid underground in parallel rows with a common manifold system, Fig. 1. By definition, these facilities will be subjected to fluctuating stresses and therefore must be designed to resist fatigue.

Pressure vessel and pipeline standards normally require a vessel/pipe 
subjected to cyclic operation to be designed to prevent fatigue failure. differ significantards have this common aim, the approaches adopted differ significantly. The approaches can be summarised as:

i) Pressure Vessel Approach

UK and American pressure vesse1 codes, BS. 5500 (Anon., 1982) and ASME VIII (Anon., 1976), incorporate fatigue design curves based on data from nominally defect free, plain or welded specimens; the philosophy being inat this type of specimen simulates a vessel that has passed rigorous nspection requirements and contains no 'major' defects.

\section{ii) Pipeline Approach}

In the United Kingdom, the Institution of Gas Engineers are soon to issue guidelines on the fatigue design of transmission pipelines. These guidelines, Edition 2 of IGE/TD/1 (Anon., 1977), will contain fatigue design recommendations based on experimental studies (Fearnehough, Jones, 1978) on linepipe containing defects just able to survive a hydrotest (proof test). The philosophy is that a successful hydrotest demonstrates a definable fatigue life for a pipelinecsin hydrotest defects remaining after the test. This apros that at the end of a defined fatigue life, a pipelin the mor advantage to demonstrate its fitness for further inspections.

As pipe arrays are buried, periodic inspections are both costly and introduce the risk of damage during excavation. Therefore, the 'Pipeline Approach to fatigue design is particularly attractive in that inspection can be replaced by direct revalidation with a hydrotest. The IGE/TD/1 recommendations for pipelines are based on extensive experimental $(>124 \mathrm{MN} / \mathrm{m})$ inepipe, but data at stress levels relevant to pipe arrays ( fatiguer test programme was parer papertion 2, and analytical work, Section 3, which formed the basis of the resulting design curves.

\section{FULL SCALE TESTS ON PIPE ARRAYS}

Eight fatigue tests were carried out on $3500 \mathrm{~mm}$ lengths of $1066 \mathrm{~mm}$ diameter x $14.3 \mathrm{~mm}$ wall thickness Grade $5 \mathrm{LX60}$ pipe, each containing flat-bottomed defect, $533 \mathrm{~mm}$ to $1067 \mathrm{~mm}$ long $\times 0.15 \mathrm{~mm}$ wide, machin a into the root of the seam weld as shown in Fig. 2. made into a pressure vessel by welding on domed ends, Fig.

For the first three vessels tested, the defects had depths such that they just survived a hydrostatic pressure test to a stress of $436 \mathrm{mN} / \mathrm{m}^{2}$ (105\% SMYS). Following the hydrotest, and 24 hour hos the three vessels was then fatigued to failure at a range $(276,241$ and $186 \mathrm{MN} / \mathrm{m}$ respect tests, the defect in than the initial tests, to allow was machined approximately $50 \%$ shallowe Each vessel was intervals during fatigue to tion procedures.

Table 1 gives details of all the above tests and Fig. 3 plots all the above and previous data (Fearnehough, Jones 1978) in standard S-N format. In the tests which involved repeated hydrotests the regions and depth of fatigue crack growth could be determined from fracture surface markings, Fig. 4 .

\section{ANALYTICAL STUDIES}

\section{i) Basis of Studies}

The maximum size of credible defect able to survive the hydrotest can be estimated using standard formulae (Shannon, 1974). Similarly, the maximum defect size able to survive the peak operational stress can be estimated. The difference between these two defect sizes is available for fatigue growth and the rate of defect growth can be calculated using standard fracture mechanics formulae such as the Paris Law (Paris, Erdogan, 1963). Consequent1y the fatigue life of a pipeline can be defined for a given hydrotest and operational stress level. In the following section this type of analysis is performed on the full scale following
tests.

\section{ii) Analysis}

The maximum sized defect which can survive a pipeline proof test $\left(a_{i}\right)$ and the critical defect at operating pressure $\left(a_{f}\right)$ are determined from the equation for failure through-the-wall of a part-wall, infinitely long defect (Shannon, 1974):

$$
\delta_{\mathrm{H}}=1.15 \delta_{\mathrm{Y}} \quad\left(1-\frac{\mathrm{a}}{\mathrm{t}}\right)
$$

where $\delta_{H}=$ hoop stress at failure, $\delta_{Y}=$ yield stress of pipe

$$
a=\text { defect depth, } \quad t=\text { wall thickness }
$$

From $a_{i}$ and $a_{f}$, the number of cycles, $N$, to failure can then be calculated from the Paris crack growth equation (Paris, Erdogan, 1963).

$$
\frac{\mathrm{d} a}{\mathrm{dN}}=C(\Delta \mathrm{K})^{\mathrm{m}}
$$

where $\frac{d a}{d r}=$ crack growth per cycle, $\Delta \mathrm{K}=$ cyclic stress intensity factor $\frac{\mathrm{da}}{\mathrm{dN}}$

and $\mathrm{m}=$ material constants.

The stress intensity factor (K) for a defect in a pressurised pipe at the deepest penetration point on the defect periphery is given by (Erdogan, Ratwani, 1974):

$$
\mathrm{K}=\delta_{\mathrm{H}} \quad \sqrt{\pi \mathrm{a}} \quad \frac{\mathrm{C}_{\mathrm{t}} \mathrm{C}_{\mathrm{C}}}{\mathrm{Q}}
$$

where $\delta_{H}=$ hoop stress, $a$. $=$ defect of depth

$\mathrm{c}_{\mathrm{t}}=$ thickness correction factor

$\mathrm{c}_{\mathrm{c}}=$ she11 curvature correction factor,

$Q=$ defect shape and plasticity correction factor 
The fractography confirmed that the defects grew in reasonable accordance with the Paris crack growth equation. Figure 5 plots the results of the analysis showing the stress intensity Figure 5 plots the results of the rate per cycle $(\mathrm{da} / \mathrm{dN})$. From the methods provided a mean fit to the versus ( $\Delta K$ ), regression in tho ${ }^{\text {PNm }}$ ). The equation, $2.42 \times 10^{-15}$ and 4.9 respectively (m/cycle, curves and Fig. 6 shows the relationship for the proposed design. the above growth law and emiricionship between predictions made using vessel tests.

DERIVATION AND DISCUSSION OF FATIGUE DESIGN CURVES FOR PIPE ARRAYS

The full scale tests and analytical curve, summarised in Fig. 7, provide a sound base for recommending design curves for pipe arrays (with the exception of a single data point 2 .

Having established an empirical/analytical curve it is standard practice to apply suitable safety factors before considering a design curve. safely factor of 10 is compatible with factors generally applied to tife of engineering structures from laboratory fatigue data.

A design curve for storage arrays incorporating a safety factor of 10 is shown in Fig. 8. The design curve defines the fatigue life which is the maximum operational stress, thus eliminating the need for a tines inspection programme.

An alternative design curve incorporating a reduced safety factor of 3 is also shown in Fig. 8 in recognition of the following factors:-

i) The fatigue data have been generated using full scale tests on actual component i.e. the stresses and service conditions have been accurately simulated.

ii) Safety factors are used to accommodate unknowns in fabrication, operation, etc. Pipe arrays are fabricated, operated and maintained to the highest engineering standards and are buried on secure sites

iii)Pipe arrays are simple structures (lengths of pipes) in which stress concentrations (e.g. nozzles) and fabrication defects (e.g. fluctuations are

Adoption of this curve allows the pipe array to be designed for a highe fatigue duty. However, use of this curve would only be permitted after

\footnotetext{
Bars attached to points on the graph shown in Fig. 5 represent the range in $\Delta \mathrm{K}$ for the corresponding value of $\mathrm{da} / \mathrm{dN}$.

2

not corroborated by thy other of the tests in 1974. The result is not similar tests on defoct
}

detailed analysis of the entire pipe array system (including materials) to confirm that conditions (i)-(iii) are satisfied.

Finally it is of interest to compare the recommended design curves with the pressure vessel standard BS.5500 (Anon, 1982). Figure 8 shows the fatigue design curve from BS.5500 to fall within the two curves. Thi illustrates the conservative nature of the BS5500 curve as the pipe array curves are based on vessels with major seam weld defects whereas the BS5500 curve is based on fatigue tests on butt welds. However it is reassuring to note that the BS5500 curve can accommodate the full scale test data reported in this paper.

\section{CONCLUSIONS}

Full scale fatigue tests and fracture mechanics analyses have allowed the fatigue life of pipe arrays to be quantified. The design curves obtained from these data can be used to define a safe fatigue life guaranteed by a hydrotest. Consequently major periodic inspections can be replaced by hydrotests as a means of revalidation. REFERENCES

Anon (1976) 'Boiler and pressure vessel code : Section VIII

Pressure Vessels', American Society of Mechanical Engineers, ASME VIII, New York, USA.

Anon (1977) 'Recommendations on transmission and distribution practice', The Institution of Gas Engineers, IGE/TD/1, Edition 1:1977, practice', The

Anon (1982) 'Specification for unfired fusion welded pressure vesse1s', British Standards Institution, BS.5500:1982, London, England.

Erdogan, F and Ratwani, M (1974) The use of COD and plastic instability in crack propagation in pipelines. In, 'Symposium on Crack Propagation in Pipelines', Institution of Gas Engineers, London.

Fearnehough, G D and Jones, D G (1978) An approach to defect tolerance in pipelines. In, 'Tolerance of flaws in pressurised components'. Institution of Mechanical Engineers, London. pp 205-227.

Paris, P C and Erdogan, F (1963) A critical analysis of crack propagation laws. J. Basic Eng., Trans, ASME, 85, Series D. p.258.

Shannon, R W E (1974) The failure behaviour of linepipe defects. Int.J.Press.Vess and Piping, 2, pp 243-255.

Sykes, B A and Brown, D (1975) A review of the technology of high pressure storage systems. In, 'Communication 973', The Institution of Gas Engineers, London.

\section{ACKNOWLEDGEMENTS}

The authors would like to acknowledge Mr D Williamson for conducting all the full scale tests and Mr G D Fearnehough for helpful discussions.

The authors also wish to thank British Gas for permission to publish this paper. 
TABLE 1 Full Scale Tests on Pipe Array Vessels, $1067 \mathrm{~mm}$ Diameter x $14.3 \mathrm{~mm} \mathrm{wt}, \mathrm{X} 60$

\begin{tabular}{ccccccc}
\hline $\begin{array}{c}\text { Test } \\
\text { Number }\end{array}$ & $\begin{array}{l}\text { Defect } \\
\text { Length } \\
\text { 2c, mm }\end{array}$ & $\begin{array}{l}\text { Mean } \\
\text { Defect } \\
\text { Depth } \\
\text { a, mm }\end{array}$ & $\begin{array}{l}\text { Cyclic } \\
\text { Stress } \\
\text { Range } \\
(\text { MN/m }\end{array}$ & $\begin{array}{c}\text { Cycles to } \\
\text { Failure } \\
\text { After } \\
\text { Hydrotest }\end{array}$ & $\begin{array}{l}\text { Time of } \\
\text { Failure }\end{array}$ & $\begin{array}{c}\text { Yield Stress } \\
\text { of Pipe } \\
\left(\mathrm{MN} / \mathrm{m}^{2}\right)\end{array}$ \\
\hline A & 787 & 2.3 & 186 & 21,470 & Fatigue & 434 \\
\hline B & 787 & 2.5 & 243 & 7,858 & Fatigue & 434 \\
\hline C & 787 & 2.8 & 276 & 5,125 & Fatigue & 434 \\
\hline 1 & 686 & 1.35 & 276 & 3,073 & Fatigue++ & 434 \\
\hline 2 & 686 & 1.32 & 241 & 7,000 & $\begin{array}{l}\text { Sixth } \\
\text { Hydrotest }\end{array}$ & 455 \\
\hline 3 & 737 & 1.37 & $\begin{array}{l}\text { (a) } 186 * \\
\text { (b) } 276\end{array}$ & 5,000 & $\begin{array}{l}\text { Second } \\
\text { Hydrotest }\end{array}$ & 455 \\
\hline 4 & 762 & 1.60 & 276 & 3,000 & $\begin{array}{l}\text { Fourth } \\
\text { Hydrotest }\end{array}$ & 455 \\
\hline 5 & 737 & 1.40 & 241 & 6,000 & $\begin{array}{l}\text { Third } \\
\text { Hydrotest }\end{array}$ & 455 \\
\hline
\end{tabular}

*Test 3 surviyed 9 hydrotests and 8 periods of 21,500 cycles at at cyclic . Vessel failed on hydrotęst after 5000 cycles

++ Failed during fatigue subsequent to fourth hydrotest.
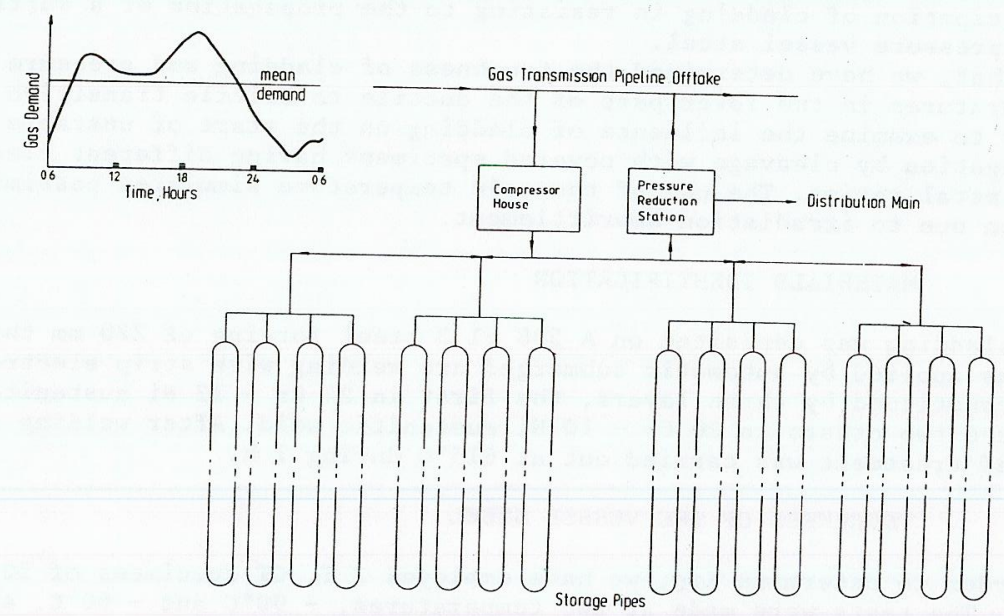

FIG 1: TYPICAL SCHEMATIC ARRANGEMENT OF A PIPE ARRAY STORAGE FACILITY

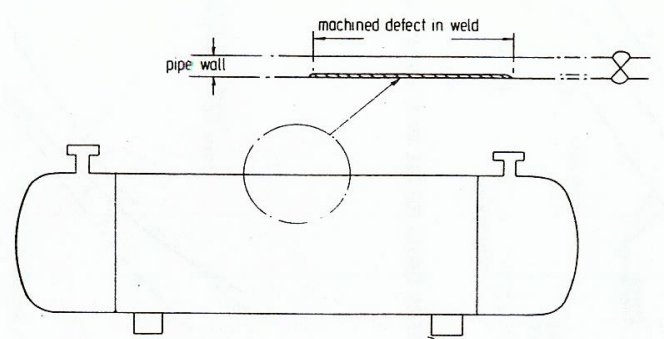

FIG 2 : SCHEMATIC OF TEST VESSEL WITH SEAM WELD DEFECT

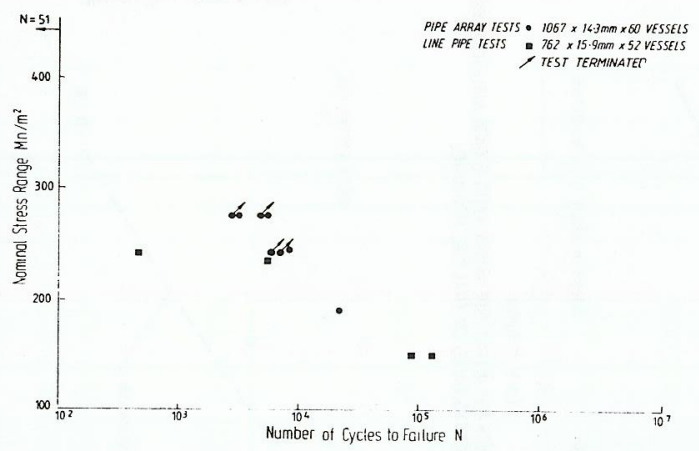

fIG 3: SUMMARY OF BRITISH GAS FULL SCALE FATIGUE TEST ON LINEPIPE \& PIPE ARRAYS
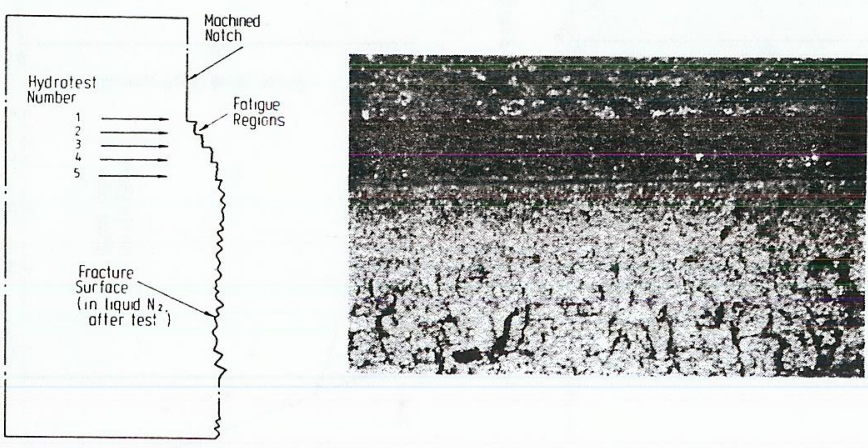

FIG 4: FRACTURE SURFACE OF MACHINED DEFECT SHOWING CRACK GROWTH 


$$
4
$$

